\title{
Stage IV Pleural Malignant Mesothelioma AJCC v8
}

National Cancer Institute

\section{Source}

National Cancer Institute. Stage IV Pleural Malignant Mesothelioma A/CC v8. NCI

Thesaurus. Code C136406.

Stage IV includes: Any T, Any N, M1. M1: Distant metastasis present. (AJCC 8th ed.) 